\title{
Managing International Alliances: Joint Ventures: A Case Study
}

\author{
Dursun Bingöl, Suat Begeç \\ Faculty of Business Administration, University of Turkish Aeronautical Association, Ankara, Turkey \\ Email: suat_begec@yahoo.com
}

How to cite this paper: Bingöl, D., \& Begeç, S. (2020). Managing International Alliances: Joint Ventures: A Case Study. Open Journal of Social Sciences, 8, 538-552.

https://doi.org/10.4236/jss.2020.84039

Received: March 16, 2020

Accepted: April 25, 2020

Published: April 28, 2020

Copyright $\odot 2020$ by author(s) and Scientific Research Publishing Inc. This work is licensed under the Creative Commons Attribution International License (CC BY 4.0).

http://creativecommons.org/licenses/by/4.0/ (c) (i) Open Access

\begin{abstract}
Companies tend to internationalize for many reasons and use various methods. Joint Ventures (JVs) are one of the most common methods to establish partnerships. Partnership enterprises benefit from the market experience of their foreign partners, transferring technology and information, resources and talent pool, and exceeding legal limitations. Although JVs provide economic benefits for companies, they face significant challenges. The aim of the study is to reveal the reasons of the companies to make strategic alliances in the international arena such as joint venture and other formations and the managerial challenges they face with a case study. This paper examines ASELSAN, which is one of the most important institutions of Defense Sector in Turkey. It analyzes the reasons of being a participant of JVs and the way of internationalization. An evaluation was made in line with the answers received from the management levels. ASELSAN's internationalization and the reasons for its participation in foreign countries coincide. However, the reason for internationalization is "increasing the international brand value of Turkey." In addition to the similarities to those provided in the literature, ASELSAN has its own unique methods in terms of the challenges and difficulties encountered in the implementation of overseas plans, control and coordination problems.
\end{abstract}

\section{Keywords}

Strategic Alliances, Joint Ventures, ASELSAN

\section{Introduction}

Because of the widespread use of fast and intensive communication opportunities, the development of new technologies, the increase in free trade across borders, and the intensification of the global competition, businesses are in an internationalization trend in order to expand their markets, increase sales, acquire 
new resources, diversify in a product or service, and minimize the risk of competition. Due to increased internationalization trends, strategic alliances are gaining importance worldwide for various reasons. Strategic alliances represent a medium that can create scale and scope advantages necessary to be competitive on a global basis (Vaidya, 2011). In this context, this paper examines ASELSAN, which is one of the most important institutions of Defense Sector in Turkey and analyzes the reasons of being a participant of JVs and the way of internationalization.

Most of the enterprises use one of the five (5) basic international structures. The first phase of internationalization takes its place in the global world through importing and exporting, licensing and franchising, strategic alliances and joint ventures, and foreign direct investment (Bovée \& Thill, 2017). Businesses, however, find themselves in a very intense competition while operating globally. Moreover, businesses influence factors such as political, cultural, economic, social, and legal. In order to provide superiority to customers in such an environment, businesses must provide customers with high-quality products at fair prices with good service (Nickels et al., 2010), develop global business strategies, create global goals and use different methods.

Nowadays, companies or business units may form a strategic alliance for a number of reasons, including; obtain or learn new capabilities, obtain access to specific markets, reduce financial and political risk (Wheelen et al., 2015). The motives of the strategic alliance are comprised of possibilities related to better and faster access to technologies, form added value and derive profit (Kinderis \& Jucevičius, 2013), gain competitive advantage over their rivals (Obioma, 2017), and consolidate forces, set new global standards, deal with competition, overcome protective obstacles, fill a gap, benefit from various sources or save on labor costs that are the other reasons for the strategic alliances. However, foreign direct investment has difficulties due to legal, political, cultural differences in every country. International firms tend to engage in joint ventures or allies in foreign countries.

Enterprises benefit from the market experience of their strategic partners, transfer technology, information, and resources from them, and exceed the legal limitations. In addition, it is not easy to carry out and sustain such mergers. In order to continue their activities in this direction effectively, companies must take into account the national cultures, political systems, economic structures of foreign countries as well as various international organizations. Because these types of alliances have a significant impact on the organizational structure and culture, management style and human resources function. For this reason, enterprises should analyze the labor structure, legal regulation, economic condition, socio-cultural structure, physical location, and political system of the country where they will operate as associates, and determine their strategic objectives according to the data obtained from the analysis. Enterprises, which are subsidiaries in overseas, must comply with their strategic objectives and local and foreign environmental requirements. 
Although there are many reasons for the strategic alliance, it is a complex and risky initiative that often fails to deliver anticipated benefits (Petruzzellis et al., 2016). Several studies, using various samples of joint ventures and other strategic alliances, have set of failure. The difficulties arising from the structure of the merger, double-headed management, and the decision-making process slowed down due to the constant discrepancy between the partners, conflicts and disagreements between the partners on the objectives (Lane \& Beamish, 1990), differences in organizational culture (Brown, Rugman \& Verbeke 1989). Especially, conflicts may lead to the dissolution of the alliance at any stage of its formation and development (Nikolova et al., 2014). Conflicts and disagreements among partners, there are also important difficulties such as; clash of cultures and incompatible personal chemistry, lack of clear goals and objectives, lack of trust, lack of coordination between management teams, differences in operating procedures and attitudes among partners, relation and performance risks. Strategic alliances especially might create a future local or even global competitor due to these associations (Elmuti \& Kathawala, 2001).

In addition, the initial conditions play an important role in the success of strategic alliances. For example, the agreement for joint venture, a type of strategic alliances should base on balanced interest and risk sharing and mutual compliance and trust. On the other hand, the reliability of partners should be evaluated in terms of management style, cost effectiveness, experience of cooperation situations, the risk of creating a potential competitor (Prevot, 2006).

It is also a fact that the pitfalls of such alliances have not been adequately studied, although considerably time and effort has been spent on revealing conditions that play an important role in the success of strategic alliances, and in particular, the tactical impetus for joint ventures as a strategic alliance.

\section{Theoretical Framework}

\subsection{Reasons for Internationalization in Partnerships}

As is known, companies need to internationalize due to reasons such as: 1) To increase sales, 2) to improve profitability, 3) to provide short-term and long-term security, 4) to increase innovation, 5) to have special market knowledge, 6) to take advantage of scale economy, 7) to learning from international markets, and 8) to increase competitiveness. However, the global economy requires companies to transform themselves into global or international companies that can compete with anybody, anywhere, anytime. This requirement means that companies use a variety of dimensions or methods to achieve a new level of competitive advantage. The global economy requires firms to transform themselves into global companies that are able to compete with anybody, anywhere, anytime. This imperative means that companies must excel in a number of dimensions that create a new level of competitive advantages (Vance \& Paik, 2006). Companies that go to internationalization use import, export, license agreements, partnerships and foreign direct investment. 


\subsection{International Joint Ventures as Alliances}

Companies can prefer to use foreign direct investment as a method of internationalization, especially because of growing, taking advantage of the labor force and resources in foreign countries and taking advantage of tax benefits. However, foreign direct investment is not allowed in many countries in order to protect political, nationalist movements and local enterprises. For this reason, companies are trying to cooperate or establish partnerships with local businesses in foreign countries. These mergers or partnerships, also called international strategic subsidiaries, have increased as a tool of choice for many years to increase the products of the companies, expand their market areas or increase their customers. International strategic alliances have been growing importance in recent years as a choice vehicle for companies to expand their product, geographic or customer reach. For example, between 1990 and 1995 the number of local and international alliances grew by more than 25 percent annually (Bleeke \& Ernst, 1995) and between 1990-1999 the number of international strategic alliances accounted for $68 \%$ (numbering 62,000) of all alliances (Kang \& Sakai, 2000). According to the Sandström and Weimer's research, there has been an overall increase in partnerships and emphasis on implementation over the past years in Europe and the European Union is the most important region for international collaboration, followed by Asia, North America and other European countries (Sandström \& Weimer, 2016).

Companies that are increasingly involved in strategic mergers, often collaborate in a shared strategy and vision practice to manage their environment and markets more effectively and increase their profits (Tayeb, 2005). The partnership between British Airways of England and Qantas of Australia can be shown as an example of a successful international partnership. In this partnership, the two airlines exchange expertise in a two-way style and share common strategies, core values, and information systems (Tayeb, 2005).

Such subsidiaries may be in the form of merger and consortium, or, as the most commonly used, joint ventures. Joint Ventures, often referred to as company marriages or joint ownership, are stated to occur when two or more companies jointly establish and own a new business or company (Can, 2015). Joint ventures are business agreements whereby two or more owners create a separate entity (Harrigan, 1988). Such a partnership can be established between local businesses as well as between a foreign company and a local business. The International Joint Venture may take the form of a company joining a local entity in a foreign country, purchasing a part of the local business, or establishing a new business with local business (Can, 2015). While joint ventures may be operational and informal, such as an agreement with two companies to share a stand at a trade show, they represent a very useful strategic choice (Clegg et al., 2019).

International Joint Ventures, a mechanism for growth and expansion, is suitable for small businesses as well as large enterprises. Because small businesses have a flexible structure and can adapt to the environment more quickly, they 
can expand or create market opportunities beyond their existing internal capacities (Tayeb, 2005). Businesses and MNCs, especially today, can explain the reasons behind entering joint venture agreements as: (Datta, 1988)

- To enter new and potentially profitable markets,

- To share high economic risks with new business partners,

- To reduce the risk of nationalism and expropriation,

- To maintain good relations with host country governments,

- To achieve synergistic benefits, bring together organizational knowledge.

On the other hand, Tayeb (2005) summarizes some of the major motives for the creation of international joint ventures. These motivators are Risk reduction, Risk decrease, Rationalization of product and scale economies, Overcome or blocking competition, Bypassing national protectionist policies, Technology development, Entry to foreign markets, Simplifying initial international enlargement, Resource expertise, Vertical integration, Diversification, Exchanges of supplementary technologies and patents, Reinforcement of market position, Acquiring lower cost locations, Market power, Market development, and Large projects.

The International Joint Ventures (IJV) provide many advantages for partners. However, the formation and maintenance of an IJV brings with its risks. In order to minimize these risks, it is necessary to follow a process in the formation of the partnership. The first step of this process is undoubtedly planning. At this stage, purpose and objectives of the partnership should be determined. The relationship has to be supported by executive leadership and formed by lower management at the highest, macro level (Išoraite, 2009). The second stage is the selection of the partner. Trust and sensibility among the partners are an important condition in maintaining the partnership after its establishment. It is a prerequisite for the success of the joint venture to select the right partners who will be trusted and experienced. Strategic alliances initiate with planned targets that strengthen the competitive power of the organizations involved in the alliance (Akpotu, 2016). The characteristics of partners must be complementary. After determining the strategic cooperation, technological (Ajao et al., 2015), market, financial, human resources requirements (Gong et al., 2005), and management studies are carried out to determine the feasibility of the partnership and whether it is worth the risk or not. After that, a written agreement is signed between the partners and the conditions, including the rights and responsibilities of each partner, are determined. These conditions include the amount of shares each partner in the partnership, management authority has, etc. No matter how meticulously the establishment phase is carried out, there is a high probability of coming across the risks involved in maintaining the partnership.

The joint venture is formed when a given opportunity is too complex, uneconomical, or risky for a single firm to pursue alone, or when an endeavor requires a broader range of competencies and know-how than any firm can marshal (Wheelen et al., 2015) (David \& David, 2017). However, unstable governments 
in the host country, fluctuating currencies, very tense communication and insufficient transport infrastructure are important risk factors in this regard (The Economist, 1986). Even though a positive climate prevails in the country where the partnership will be established, during the formation of the partnership, it may change further. For example, nationalist movements are a danger for foreign partners. Apart from these, a joint venture analysis also requires an adequate assessment of the objectives of host country government. While the role of the host country government may be direct or indirect, any one may rarely reduce its influence. In fact, a joint venture strategy selects out of the need to meet the objectives of the host country government (Datta, 1988). The aims of these governments are the employment of the local workforce in JV organizations, import substitution, foreign exchange, and the minimization of foreign control of local industry (Wright \& Russel, 1975), shared control of business and risk of losing specialized technology the partners (Solomon et al., 2016). In addition, differences in legislation and, of course, diversities, above all, pose risks.

There are also structural and managerial reasons as well as external environmental factors that prevent the existence of IJVs and even other strategic alliances. Therefore, the life of these alliances does not last much longer. Such as, Bleeke and Ernst (1995) point out, the term alliance can be deceptive. In many cases, an alliance really means an eventual transfer of ownership. The median life span for alliance is only about seven years, and nearly 80 per cent of joint ventures-one of the most common alliance structures-ultimately end in a sale by one of the partners (Peng \& Shenkar, 2002). Many reasons such as strategic misfit, preoccupation with short-termism, and incompatible organizational and human resource management policies have been offered by researchers as the causes of the relatively high failure rate of alliances (Tayeb, 2005). For instance, a major cause for cooperative failure is managerial behavior. In nature, cooperation differs fundamentally from the competition. Whereas competitive processes are well understood and practiced daily, the key success factors in cooperative processes are widely ignored in the same vein, (Niederkofler, 1991). A researcher asserts that alliances fail because operating managers do not make them work, not because contracts are poorly written (Harrigan, 1986).

\subsection{Management and Implementation of Joint Ventures}

As mentioned before, partnerships, especially, joint ventures have significant economic benefits in foreign countries. However, significant costs arise in the implementation of these partnerships, because, in these initiatives, people who have different goals, different expectations, different cultures and different characteristics establish partnerships. On the other hand, there are problems in the management of these partnerships. Shared decision-making makes them difficult to manage. Such a situation tends to form fragile relationships with high failure rates. In fact, in a study, the failure rate was found to be $45 \%$ - $50 \%$ (Beamish, 1985). Behavioral, cultural and managerial obstacles play a priority role in 
the failure of the implementation of joint ventures. These barriers make it a challenging task for senior executives of a joint venture to be effective (Datta, 1988). For instance, different organizational barriers, such as departmentalization structures, exist which limits the ability to transfer information across the intra-organizational barriers (Heimeriks \& Duysters, 2007). For that reasons the joint ventures are hard to control, and a delay or performance misfortune by any participating business delay the others and cause project problems (Daniels et al., 2019).

Culture is one of the most important factors affecting the success of IJVs. Culture has a significant effect in shaping the laws of a country, the values of the people of that country, consumption habits, working styles, relations between people, etc. However, the culture of each nation is different and the manager of the partnership should consider this diversity. Because the diversities in people's values, beliefs and behavior patterns are important for international alliances. Many of the problems and misunderstandings in joint venture stems from the cultural diversity present at both national and organizational levels (Datta, 1988). This situation shows the necessity of international human resources management. Because, behavioral and cultural differences between partners cause conflicts. Therefore, the situation should analyze during the formation of joint ventures.

One of the other important issues in the implementation of the International Joint Ventures is the determination of managers. When the partnership agreement is over, it is decided which partner will be the dominant in the management of the joint venture or a shared management is decided. If the foreign company owns more than $50 \%$ of the venture, they send expatriate to the management of this partnership. Although the cost of sending managers from the home country is high, there are important reasons for the partner company. We can list these reasons as follows:

- Partner companies can supervise their foreign subsidiaries in these countries.

- As is known, every organization wants its own organizational culture to be valid in common companies. For this reason, expatriates work in the organizational culture.

- One of the most important problems is control of the partnership. The expatriates may do this control effectively.

\section{Research}

The aim of the study is to reveal the reasons of the companies to make strategic alliances in the international arena such as joint venture and other formations and the managerial challenges they face with a case study.

In this context, we will examine the ASELSAN example, which is one of the most important institutions of the Defense Sector in our country. We will also analyze the reasons of being a participant of the joint ventures and the way of internationalization. In addition, the process of formation and maintenance and 
the ways in which these problems are solved. We sent a letter that includes eleven (11) questions to the ASELSAN representatives. We try to examine due to the response of the legal representative of the ASELSAN.

\subsection{Information about the ASELSAN}

On their website, ASELSAN defines itself as "a Turkish Armed Forces Foundation Company. In order to serve the communication necessities of the Turkish Army by national needs, it was founded in 1975. 25.7\% of the total amount of shares runs in the İstanbul Borsa stock market whereas the remaining $74.2 \%$ of the shares are owned by the Foundation. ASELSAN is the huge Turkish defense electronics company whose capability/product portfolio comprises air defense and missile systems, automation, avionics, command and control systems, communication and information technologies, electro-optics, land, naval and weapon systems, medical systems, radar and electronic warfare, security, traffic, transportation, and unmanned systems (ASELSAN, 2019).

As Turkey is a member country of NATO, ASELSAN maintains its production in accordance to NATO Quality Assurance Standards and international military standards for the products distributed to both internal and external markets. ASELSAN operates in the fields of the design, development, production, system integration, and after-sales services of Military Communications Systems, Command, Control, Communication, Computer, Intelligence Reconnaissance and Surveillance Systems, Electro-Optic Systems, Electronic Warfare Systems, Navigation and Avionic Systems, Naval Systems, Radar Systems, Traffic and Toll Collection Systems, Unmanned Systems, and Weapons Systems (ASELSAN, 2019).

ASELSAN exports these indigenous products in international markets through different cooperation techniques with local partners and listed as one of the top 100 defense companies of the world (Defense News Top 100). ASELSAN has aimed to be a company that keeps its sustainable growth by creating value in the global market; preferred due to its competitiveness, trusted as a strategic partner, and caring for the environment and people (ASELSAN, 2019). One of the partnership of ASELSAN is SADEC LLC. Table 1 shows that the Local and Global Subsidiaries, Affiliates and Marketable Securities of ASELSAN.

The registration of SADEC LLC Corporation was completed on 27 December 2016 as part of its efforts to establish a joint venture with TAQNIA DST in Saudi Arabia. The capital of the company is SAR 22.5 million (USD 6 Million). With a 50\%-50 percentage partnership between ASELSAN and TAQNIA DST to carry out the production, development and maintenance, repair of electronic devices and systems to meet Saudi Arabia's requirements for radar, electronic warfare and electro-optical systems. It is planned that the necessary infrastructure and production facility investments of the Company will be completed within two years (ASELSAN Annual Report, 2017). 
Table 1. The local and global subsidiaries, affiliates and marketable securities of ASELSAN.

\begin{tabular}{|c|c|c|c|}
\hline Local Subsidiaries & Name of the Subsidiaries & Share Amount & ASELSANs Share (\%) \\
\hline 1 & $\begin{array}{l}\text { ASELSANNET Elektronik ve Haberleşme Sistemleri Sanayi } \\
\text { Tic. İnşaat ve Taahhüt Ltd. Şti. }\end{array}$ & $3.300 .000 .00 \mathrm{TL}$ & 100.00 \\
\hline 2 & Mikro Elektronik Ar-Ge Tasarım ve Tic. Ltd. Şti & $55.250 .00 \mathrm{TL}$ & 85.00 \\
\hline 3 & YİTAL Mikro Elektronik Sanayi ve Ticaret A.Ş. & $8,905,875.00 \mathrm{TL}$ & 51.00 \\
\hline 4 & ASELSAN Hassas Optik San. ve Tic. A.Ş. & $6.500 .000 .00 \mathrm{TL}$ & 50.00 \\
\hline 5 & ASELSAN BİLKENT Mikro Nano Tek. San. ve Tic. A.Ş. & 9.000.000.00 TL & 50.00 \\
\hline 6 & ROKETSAN Roket San. ve Tic. A.Ş. & 21.906.222,86 TL & 14.897 \\
\hline 7 & ASPILSAN Enerji San. ve Tic. A.Ş. & $56.000 .00 \mathrm{TL}$ & 1.00 \\
\hline Global Subsidiaries & Name of the Subsidiaries & Share Amount & ASELSANs Share (\%) \\
\hline 1 & ASELSAN Baku Company & 1.735.212,00 USD & 100.00 \\
\hline 2 & ASELSAN Malaysian Sdn. Bhd. & 100 Malaysian Ringit & 100.00 \\
\hline 3 & SADEC LLC. (Saudi Defense Electronics Company) & 11.250.000 Saudi Arabian Riyal & 50.00 \\
\hline 4 & ASELSAN Middle East PSC. Ltd. & 1.225.000,00 Jordanian Dinar & 49.00 \\
\hline 5 & IGG ASELSAN Integrated Systems LLC. & 98.000,00 UAE Dirham & 49.00 \\
\hline 6 & $\begin{array}{l}\text { Kazakhstan ASELSAN Engineering LLP. } \\
\text { - (ASELSAN Annual Report, 2017) }\end{array}$ & 3.464.300.000,00 Kazakhstan Tenge & 49.00 \\
\hline
\end{tabular}

\subsection{Questions, Answers and Comments ( $Q, A$ \& $C)$}

Q 1: What are the reasons for the internationalization of ASELSAN?

A 1: With its vision "To be a reliable, competitively preferred, environment-friendly and human conscious technology firm, which preserves its sustainable growth in the global market via the values, created for stakeholders, as well as serving its establishment purposes". And in the framework of its mission "By focusing primarily on the needs of the Turkish Armed Forces, to provide high-value-added, innovative and reliable products and solutions to both local and foreign customers in the fields of electronic technologies and system integration; continuing activities in line with global targets as well as increasing brand awareness and contributing to the technological independence of Turkey". The causes of internationalization of ASELSAN;

- Contributes to the sustainable growth target (market access),

- To be able to offer added value products to the world markets,

- Increasing competitiveness,

- Benefits from the international markets (cost, know-how, experience) and

- To increase its brand value in the global market.

Q 2: What are the reasons for the strategic allies in foreign countries of ASELSAN?

A 2: It is an important tool for achieving its vision and mission to realize local cooperation with foreign countries and to realize this vision strategically and economically. For this reason, there are strategic allies in foreign countries that 
are considered to contribute to achieve these aims.

$\mathrm{Q}$ 3: What are the reasons for ASELSAN Baku Company's direct investment?

A 3:

- To develop military, technological, strategic and economic cooperation at the highest level with Azerbaijan, which has an important historical, cultural and strategic connection.

- To ensure that the maintenance, repair and maintenance activities of our products sold in Azerbaijan are carried out and carried out fast.

$\mathrm{Q}$ 4: Is there an assigned company executive from Turkey in ASELSAN Baku Company?

A 4: Company Director appoints from Turkey.

$Q$ 5: What are the advantages and disadvantages in the formation and the realization of strategic allies?

A 5:

- Advantages

- ASELSAN s brand image,

- Company experience in international company foundation and partnership,

- Well bilateral relations,

- Economic, commercial and technological cooperation between partner countries.

- Challenges:

- Negotiation processes related to the Company's articles of association and partnership privileges,

- Differences in legislation,

- Political risks,

- Cyclical risks.

Q 6: How is control and coordination carried out in your allies? A 6:

- There is a directorate responsible for coordination.

- Control and coordination are ensured by this directorate;

- The presence of ASELSAN representatives on the Company's Board of Directors,

- Appointment of the manager by ASELSAN,

$\checkmark$ Establishment of decision making mechanism (unanimous decision of Board of Directors, etc.),

- Arrangements of the main contract,

- Ensuring regular information flow from subsidiaries and affiliates,

- Internal and external audit carried out in affiliates and its subsidiaries.

Q 7: What are the criteria for selection and appointment of managers in SADEC LLC, where there is $50 \%$ participation? Is it from the host country or from the allies' country?

A 7: According to the signed protocol, the Company General Manager (CEO) must be a Saudi citizen and the Company Technical Manager (COO) must be a 
Turkish citizen. The SADEC Board of Directors appoints the candidates proposed by the partners.

Q 8: How did the appointment of managers in the partnership where $49 \%$ of the shares?

A 8: In such affiliates, the Company's articles of association, the company manager being a Turkish citizen, as well as the deputy director positions are considered to be a local manager. The Board of Directors appoints the proposed candidates.

Q 9: What are the problems about social, cultural and legal diversities in investments and affiliates? How were these problems overcome?

A 9:

- Local expert support is available on legal issues.

- Cultural and social differences are solved by the communication at each stage.

- Such problems are diminishing with learning effect over time.

Q 10: What are the steps of ASELSAN's strategic allies in a foreign country?

A 10:

- Intention agreements between countries and companies,

- Concrete project and cooperation opportunities,

- Company foundation,

- Establishing the organizational framework of the company,

- Acquisition of core competencies,

- Ensuring transactions and information flow related to partnership rights,

- Harmonization of the parent company and its affiliate aims and strategies,

- Transition to other stages of maturity.

Q 11: How does ASELSAN's planning process take place in strategic allies?

A 11:

- The Board of Directors approves the annual budget and activity plan.

- Periodic meetings are held with our associates and affiliates on the activities and strategic targets.

- The executives assigned to the associate periodically report to the Board of Directors of ASELSAN and take the expectations of the Board of Directors of ASELSAN for the following period.

\section{Conclusion}

This paper focuses on the partnership implementation of IJV as the example of the ASELSAN. ASELSAN is a Turkish Armed Forces Foundation company in order to serve the communication necessities of the Turkish Army by national needs since 1975. Even if ASELSAN has other global and local Subsidiaries, we examine the joint venture form of the SADEC LLC Corporation with TAQNIA DST in Saudi Arabia. 
This international joint venture has significant advantages and challenges. According to the response, market access, cost, know-how, experience, brand image, company experience, bilateral relations, economic, commercial and technological cooperation between partner countries are advantages and negotiation processes, differences in legislation, political and cyclical risks are the main disadvantages. These reflect the similarities of the literatures of the international partnerships. International joint venture is like a marriage. You need to spend time and challenge into the relationship with your partner.

In the qualitative study we conducted in relation to ASELSAN, it was trying to determine why ASELSAN was going to internationalize.

According to the results, it is determined that ASELSAN is internationalized due to the reasons mentioned in the theoretical section. However, ASELSAN has a different reason than the literature suggested, for this reason, "increasing the brand value of our country in the international arena". In this context, its presence in foreign countries depends on the company's vision and strategic objectives.

ASELSAN carries out the formation of its foreign subsidiaries in a certain process. Our explanations about this process and its steps can contribute to the literature. On the other hand, it is stated that ASELSAN's brand image provides facilities for the formation and implementation of subsidiaries. It emphasizes that there are important challenges in the formation process of legislative differences and politicians. There is no answer to the fact that cultural differences constitute an obstacle.

The appointment of managers in foreign countries is one of the most debated issues in the literature. The investment manager is appointed in ASELSAN Baku from Turkey as a Company Director. The company manager must be a Saudi citizen and the Company Technical Manager should be a Turkish citizen.

It is envisaged that the company manager will be a Turkish citizen in the institutions where there is a $49 \%$ stake, as well as the appointment of assistant managers from the host country. As is known, the control and coordination of foreign subsidiaries are important. For this reason, ASELSAN considers appointing managers to these institutions, taking unanimous decisions of the board of directors, in particular, and ensuring a regular flow of information from subsidiaries and affiliates.

As a general consideration, ASELSAN continues its relationships in the same way as in the process of establishment. When we designed this study, we aimed to do an in-depth case study. However, it was not possible to obtain the necessary information for an in-depth study from ASELSAN. They just gave us general information.

Therefore, we would like to mention that it would be useful for those who will do research in this field. Researching the applications of internationalized companies of our country scientifically will contribute significantly to the literature and Turkish Companies. 


\section{Conflicts of Interest}

The authors declare no conflicts of interest regarding the publication of this paper.

\section{References}

Ajao, B. F., Oyebisi, T., Aderemi, H., \& Jegede, O. (2015). Status and Impact of Strategic Technology Alliances among Telecommunications Firms in Nigeria. International Journal of Business Performance Management, 16, 339-351. https://doi.org/10.1504/IJBPM.2015.068723

Akpotu, C. (2016). Strategic Alliance and Operational Sustainability. Review of Social Sciences, 1, 57. https://doi.org/10.18533/rss.vli8.57

ASELSAN (2019). https://www.aselsan.com.tr/en-us/about-us/Pages/Default.aspx

ASELSAN Annual Report (2017). https://www.aselsan.com.tr/en-us/InvestorRelations/Documents/Annual\%20Reports/A SELSAN 2017.PDF

Beamish, P. W. (1985). The Characteristics of Joint Ventures in Developed and Developing Countries. Columbia Journal of World Business, 20, 13-19.

Bleeke, J., \& Ernst, D. (1995). Is Your Strategic Alliance Really a Sale? Harvard Business Review, 97-105.

Bovée, C. L., \& Thill, J. V. (2017). Business in Action (pp. 109). Harlow, Essex: Pearson Education Limited, Edinburgh Gate.

Brown, L. T., Rugman, A. M., \& Verbeke, A. (1989). Japanese Joint Ventures with Western Multinationals: Synthesising the Economic and Cultural Explanations of Failure. Asia Pacific Journal of Management, 6, 225-242. https://doi.org/10.1007/BF01733766

Can, E. (2015). Uluslararası İşletmecilik. 5. Baskı, Beta, İstanbul.

Clegg, S. R., Schweitzer, J., Whittle, A., \& Pitelis, C. (2019). Strategy: Theory and Practice (3rd ed., pp. 262). New York: SAGE Publishing.

Daniels, J. D., Radebaugh, L. H., \& Sullivan, D. P. (2019). International Business: Environments \& Operations (16th ed., pp. 459). Harlow: Pearson.

Datta, D. K. (1988). International Joint Ventures: A Framework for Analysis. Journal of General Management, 14, 78-91. https://doi.org/10.1177/030630708801400205

David, F. R., \& David, F. R. (2017). Strategic Management: A Competitive Advantage Approach, Concepts and Cases (16th ed., pp. 138-139). Essex, England: Pearson Education Limited.

Elmuti, D., \& Kathawala, Y. (2001). An Overview of Strategic Alliances. Management Decision, 39, 205-218. https://doi.org/10.1108/EUM0000000005452

Gong, Y., Shenkar, O., Luo, Y., \& Nyaw, M. K. (2005). Human Resources and International Joint Venture Performance: A System Perspective. Journal of International Business Studies, 36, 505-518. https://doi.org/10.1057/palgrave.jibs.8400154

Harrigan, K. R. (1986). Managing for Joint Venture Success. Boston, MA: Lexington Books.

Harrigan, K. R. (1988). Joint Venture and Competitive Strategy. Strategic Management Journal, 9, 141-158. https://doi.org/10.1002/smj.4250090205

Heimeriks, K. H., \& Duysters, G. (2007). Alliance Capability as a Mediator between Experience and Alliance Performance: An Empirical Investigation into the Alliance Capability Development Process. Journal of Management Studies, 44, 25-49. 
https://doi.org/10.1111/j.1467-6486.2006.00639.x

Išoraitè, M. (2009). Importance of Strategic Alliances in Company's Activity. Intellectual Economics, 1, 39-46.

https://www3.mruni.eu/ojs/intellectual-economics/article/view/1207/1155

Kang, N. H., \& Sakai, K. (2000). International Strategic Alliances: Their Role in Industrial Globalization (pp. 1-48). OECD.

https://www.oecd-ilibrary.org/docserver/613723204010.pdf?expires=1585298492\&id=i $\underline{\mathrm{d} \& \text { accname }=\text { guest } \& \text { checksum }=\text { D64FA2EB6DC9AF732FA4AF320BD09655 }}$

Kinderis, R., \& Jucevičius, G. (2013). Strategic Alliances-Their Definition and Formation. Latgale National Economy Research, 1, 106.

https://doi.org/10.17770/lner2013vol1.5.1155

Lane, H., \& Beamish, P. (1990). Cross-Cultural Cooperative Behavior in Joint Ventures in LDCs. International Review, 30, 87-102.

Nickels, W. G., McHugh, J. M., Susan, M., \& McHugh, S. M. (2010). Understanding Business (9th ed., pp. 39). New York: McGraw-Hill Companies Inc.

Niederkofler, M. (1991). The Evolution of Strategic Alliances: Opportunities for Management Influence. Journal of Business Venturing, 6, 237-257. https://doi.org/10.1016/0883-9026(91)90018-9

Nikolova, L. V., Rodionov, D. G., \& Mokeeva, T. V. (2014). The Formation of the Conflicts Management Models of the Strategic Alliances under the Conditions of the Globalization. Asian Social Science, 10, 296.

https://doi.org/10.5539/ass.v10n19p296

Obioma, H. O. (2017). Aligning Small and Medium Enterprises for Competitiveness in Nigeria: The Role of Strategic Alliance. Review of Public Administration and Management, 5. https://doi.org/10.4172/2315-7844.1000215

Peng, M. W., \& Shenkar, O. (2002). Joint Venture Dissolution as Corporate Divorce. Academy of Management Executive, 16, No. 2. https://doi.org/10.5465/ame.2002.7173550

Petruzzellis, L., Gurrieri, A. R., Pezzi, A., \& Lenoci, M. L. (2016). Strategic Alliances between Japanese-Western Companies: A Win-Win or Win-Lose Relationship? The Case of the Automobile Industry. International Journal of Business and Management, 11, 1. https://doi.org/10.5539/ijbm.v11n11p1

Prevot, F. X. (2006). Evolution of an International Joint Ventures. The Case of a French-Brazilian Joint Venture. Thunderbird International Business Review, 48, 297-319. https://doi.org/10.1002/tie.20097

Sandström, A. M., \& Weimer, L. (2016). International Strategic Partnerships. European Association for International Education.

https://pdfslide.net/documents/international-strategic-partnerships-eaieorg-fc2878fa-c 465-4117-b573-6dedc6930d86kingdoms.html

Solomon, M. R., Poatsy, M. A., \& Martin, K. (2016). Better Business (pp. 133). London: Pearson Education Limited.

http://www.vlebooks.com/vleweb/product/openreader?id=none\&isbn=9781292099545

Tayeb, M. H. (2005). International Human Resource Management. A Multinational Company Perspective. Oxford: Oxford University Press.

The Economist (1986). Competing by Collaborating (pp. 19).

Vaidya, S. (2011). Understanding Strategic Alliances: An Integrated Framework. Journal of Management Policy and Practice, 12, 90-100.

https://www.semanticscholar.org/paper/Understanding-Strategic-Alliances\%3A-An-In 
tegrated-Vaidya/d72c41aaa5f9bac5921df14b57fa6329be4583e9

Vance, M. C., \& Paik, Y. (2006). Managing a Global Workforce. Challenges and Opportunities in International Human Resources Management (p. 79). New York: M.E. Sharpe.

Wheelen, T. L. et al. (2015). Strategic Management and Business Policy: Globalization Innovation, and Sustainability (14th ed., pp. 211-212). London: Pearson Education Limited.

Wright, W. W., \& Russel, S. S. (1975). Joint Ventures in Developing Countries: realistic and Responses. Columbia Journal of World Business, 10, 74-80.

\section{Abbreviations and Acronyms}

ASELSAN: Askerî Elektronik Sanayi (Turkish Armed Forces Foundation Company) 